\title{
HEPATIC CIRCULATION AND HEPATIC FUNCTION DURING ANAESTHESIA AND SURGERY*
}

\section{A Galindo, M D}

ThE HEPATIC DaMage which may follow anaesthesia and surgery is often considered to be a direct toxic effect of the anaesthetic agent used ${ }^{1-5}$ However, there is a possibility that this injury, usually centiolobular necrosis, and often indistunguishable from damage due to infection, ${ }^{6-8}$ is produced by liver hypoxaa of systemic or local circulatory origin The effect of prolonged systemic hypoxa in the occurrence of liver necrosis is well known durng shock, ${ }^{9}$ cardiac fallure, ${ }^{10}$ respiratory insufficiency, ${ }^{11}$ asphyxia, ${ }^{12}$ low atmospheric pressure, ${ }^{13}$ and thyrotoxicosis ${ }^{14}$ Whether shoit periods of systemic hypoxia, such as might occur during surgery, can also damage the liver is unknown at the present tume The hepatic curculatory changes associated with surgery and their role in the development of this lesion are also unknown

The sequence of events leading to the production of centrolobular necrosis by carbon tetrachloride, chloroform, and other anaesthetic agents is the subject of much discussion From biochemical data, Calvert, Moore, and Brody ${ }^{15} 18$ conclude that the first event in $\mathrm{CCl}_{4}$ poisoning is interference with the hepatic circulation producing ischaemic anoxia and necrosis Experiments of Brody and co-workers suggest that the hepatic circulation is protected by sympatholytic drugs, adrenalectomy, or spinal cord section ${ }^{17}{ }^{18}$ It is postulated that high oxygen concentration offers similar protection ${ }^{19}$ '0 Brauer and co-workers, ${ }^{21}{ }_{22}$ however, believe that the primary action of the hepatotoxic agents is the production of a cellular lesion and only secondarily a cuculatory imparment Therefore, in the absence of curculatory changes, the initial injury would not develop into necrosis, protection would be provided by alteration of the course of the lesion rather than by prevention of the initial damage

If drugs alone are being considered, the site and type of the injury may be related to the method of administration The injection of carbon tetrachloride through the portal vein produces diffuse haemorrhagic liver necrosis ${ }^{23}$ which differs from the centrolobular necrosis produced when the drug is inhaled Using this difference as a basis, Glynn and Himsworth strongly support the circulatory imparment theory ${ }^{24}$ Carbon tetrachloricle and chloroform, when administered through the systemic circulation, affect the central part of the hepatic lobules, theoretically the least exposed to the drug and also the least oxygenated part of the hepatic tissue

It seems clear from the avalable information that regardless of any hepatotoxic effect, the hepatic damage that might follow the administ ation of some anaesthetic agents is directly related to hepalic hypoxia Whether this injury is

\footnotetext{
*From the Department of Neurology and Neurosurgery, McGill University and the Montreal
} Neurological Institute and Hospital 
mediated through their systemic or local hepatic curculatory effects is unknown.

The subject of this study is, first, to determine alterations in the liver curculation under various surgical conditions, second, to standardize a hepatic lesion and observe its inherent curculatory changes, and thurd, to determine the effect of these circulatory changes on the hepatic lesion (The last two parts-II, The Effect of Various Anaesthetic Agents, and III, Chloroform-Induced Liver Damage -are in press in this Journal )

\section{HEPATIC HAEMODYNAMICS UNDER SURGICAL CONDITIONS}

Hepatic blood flow may be measured using indirect methods based on the Fick principle ${ }^{2526}$ These studies have limited value since it is not possible to differentuate between the portal venous flow and the hepatic artery blood flow, moreover, no contunuous recordings are possible Other authors use in situ perfusion of the liver, ${ }^{27}{ }^{28}$ which gives important information on the pressure/flow relationship, but interferes with the normal hepatic circulation $A$ third possibility, that used in this study, is the use of electromagnetic blood-flow meters ${ }^{29-31}$ placed around the hepatic artery ${ }^{32}$ and the portal vein Although the surgical preparation and anaesthesia can by themselves interfere with the hepatic circulation, this last method may give reliable and valuable information, provided a simple surgical technique and light anaesthesia are employed

This paper describes a technique utilizing electromagnetic blood-flow meters placed around the hepatic artery and the portal ven with as little interference to intraperitoneal structures as possible Observations on alterations in blood gases, systemic blood pressure, and the effects of some catecholamines on the hepatic blood flow and the portal $\mathrm{O}_{2}$ and $\mathrm{CO}_{2}$ partial pressures are also presented

\section{METHOD}

Seventy mongrel dogs averaging $18 \mathrm{~kg}$ in weight were used Each animal was anesthetized with an intravenous injection of thiopental $(20 \mathrm{mg} / \mathrm{kg}$ ) and art1ficially ventilated with 100 per cent oxygen by means of an endotracheal tube and a Bird Mark VIII respirator Muscular paralysis was acheved by intermittent intravenous injections of succinylcholine, $20 \mathrm{mg}$ every 30 minutes

Right atrial (central venous) pressure and abdominal aortic pressures were determined by means of plastic catheters advanced through the femoral vessels Portal venous pressure was measured with a polyethylene catheter introduced through a gastric vein The mean systemic arterial pressure was obtained by electrical integration of the artenal pressure pulse Hepatic artery vascular resistance was calculated as the ratio of mean systemic arterial pressure in mm Hg to hepatic artery blood flow in flow units per minute These flow units are presented as cubic centimeters per minute in the various figures However, all calculations were made as relative changes fiom control observations in the same expenment, and in no case were these compared to the flows in dufferent experuments In some experiments cardiac output was measured by the same electromagnetic blood-flow technique 
Lead II of the electrocardiograph and a fronto-occipital electro-encephalographic lead were recorded along with the other vanables on a Sanborn 150 oscillograph

After exposing the hepatic hilus, a 2-mm electromagnetic flow-metel probe was carefully placed around the hepatic artery A second probe was used in the portal vein The hilus was exposed through an incision in the left 11th intercostal space and incision of the left diaphragm (F1g 1).

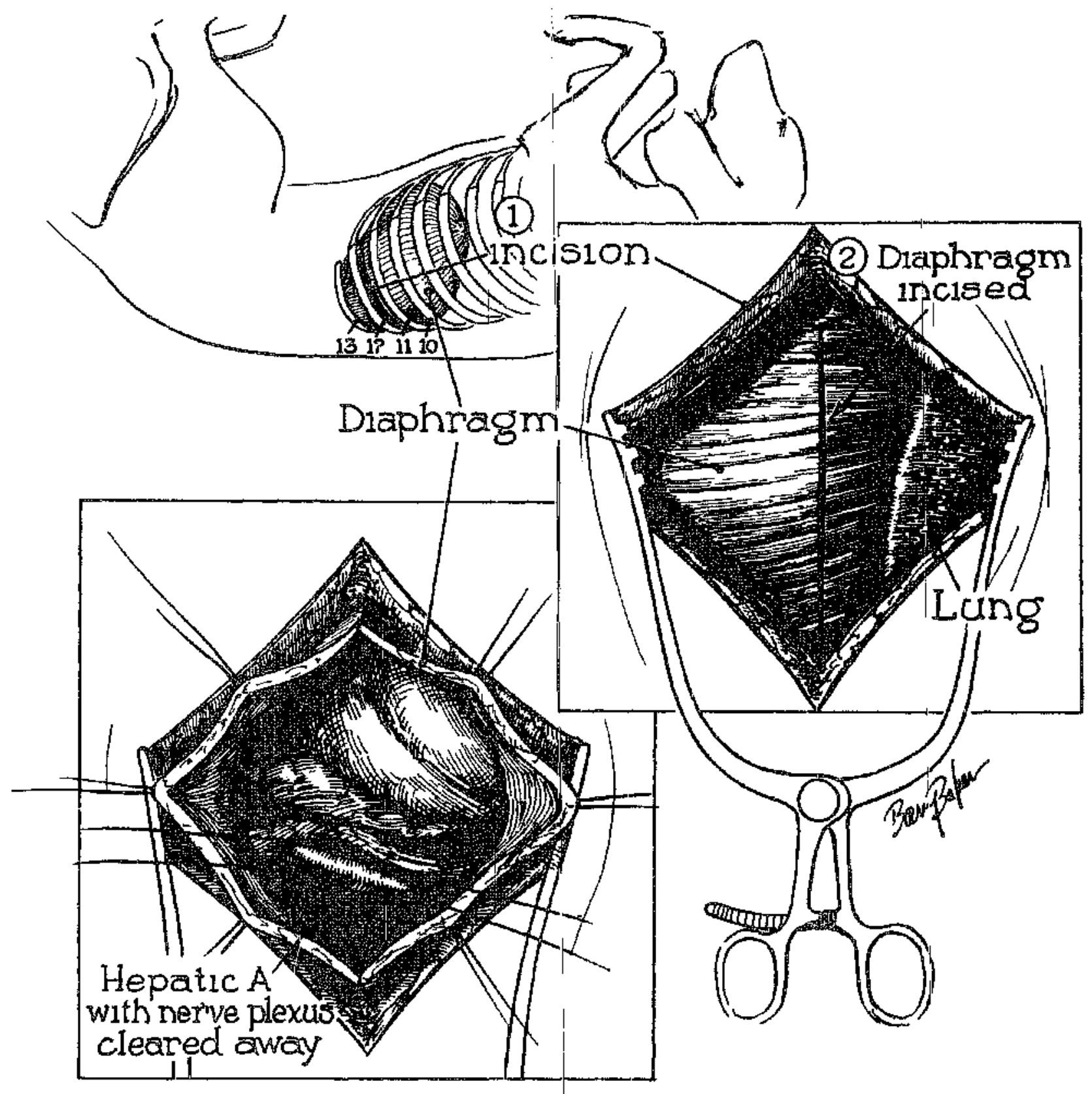

Figune 1 Surgical technique for localization of the hepatic hilus

The principle and technique of the electromagnetic method for blood-flow determinations used in the present studies have been described in detal elsewhere ${ }^{29-31}$ In this report, flow was expressed in relative changes from control observations, the error introduced thus being small ( $\pm 5 \%$ )

Systematic arterial and portal vein blood samples were analysed frequently for $\mathrm{pH}, p \mathrm{CO}_{2}$, and $p \mathrm{O}_{2}$, using a polarograph Each animal was maintained for at least one hour at normal $\mathrm{pH}, p \mathrm{CO}_{2}$, and $\mathrm{pO}_{2}$ Modufications of the parameters obtained durnng this period were considered as the normal variability, or base-line of this preparation 
The following observations were made in groups of 3 to $10 \mathrm{dogs}$ (A) the effects of increased arterial $p \mathrm{CO}_{2}(>48 \mathrm{~mm} \mathrm{Hg}),(\mathrm{B})$ the administration of 100 per cent $\mathrm{O}_{2}$ at 1 and 2 atmospheres of pressure, (C) metabolic acidosis, (D) hepatic trauma as produced by compression (retractor) of the hepatic hilus, $(\mathrm{E})$ haemorrhage $(10-20 \mathrm{c} \mathrm{c} / \mathrm{kg}),(\mathrm{F})$ cold $\left(8^{\circ} \mathrm{C}\right)$ and warm $\left(27^{\circ} \mathrm{C}\right)$ blood transfusion

The following drugs were administered intravenously to groups of 5 dogs epınephrine (1-3 $\mu \mathrm{g} / \mathrm{kg})$, norepinephrine (02-1 $\mu \mathrm{g} / \mathrm{kg})$, methoxamme (Vasoxyl) (01 mg/ $\mathrm{kg})$, mephentermine (Wyarnine) $(015 \mathrm{mg} / \mathrm{kg}$ ), acetylcholıne (02 $\mathrm{mg} / \mathrm{kg})$, metaramine (Aramine) $(01 \mathrm{mg} / \mathrm{kg})$, isoproterenol hydrochloride ( $1 \mu \mathrm{g} / \mathrm{kg}$ ), and ephedrine sulphate $(2 \mathrm{mg} / \mathrm{kg})$.

The following agents were injected into the portal vein to groups of 5 dogs histamine phosphate (002 $\mathrm{mg})$, acetylcholine ( $1 \mathrm{mg})$, epinephrine $(4 \mu \mathrm{g})$, norepinephrine $(2 \mu \mathrm{g})$, isoproterenol hydrochloride ( $\mathrm{L} \mu \mathrm{g}$ )

The effect of total sympathetic block by epidural anaesthesia was determined in 10 animals The hepatic hilus was infiltrated with $5 \mathrm{cc}$ of 1 per cent. lidocaine in four animals

\section{Results}

\section{General Pattern of Hepatic Blood Flow}

Although hepatic blood flow, that is, hepatic artery blood flow plus portal vein blood flow, is readily modified under vanou; curcumstances, a general pattern emerged Portal venous blood flow is mostly passive and follows systemic curculatory changes, mainly in central venous and systemic arterial pressures Hepatic arterial blood flow is, with some limitations, independent of systemic arterial blood pressure and responsive to the various pharmacological agents as well as to blood $\mathrm{pH}, p \mathrm{O}_{2}$, and $p \mathrm{CO}_{2}$ Differences between the arterial and portal blood $p \mathrm{O}_{2}$ and $p \mathrm{CO}_{2}$ are mostly dependent upon portal blood flow, which in turn depends upon the systemic venous and artel al pressures

The blood flow in the hepatic artery is phasic with waves of irregular frequency, one every 30 seconds to 3 minutes These phasic changes are characterized by irregularity of appearance and variable volume per wave unit as seen in Figure 2 The waves in the hepatic artery flow disappear following unskilled surgery, metabolic acidosis, or deep anaesthesia

\section{Effects of Alteration in Blood Gases}

The $p \mathrm{O}_{2}$ in the portal vein is $80-100 \mathrm{~mm} \mathrm{Hg}$ under ventilation with 100 per cent oxygen and $40-80 \mathrm{~mm} \mathrm{Hg}$ under ventilation with air However, great variation in these values was observed Hypotension decreased the portal $p \mathrm{O}_{2}$ and increased the portal $p \mathrm{CO}_{2}$ in proportion to the portal blood flow reduction (Table I)

The mhalation of 100 per cent $\mathrm{O}_{2}$ at $\mathrm{I}$ or 2 atmospheres of pressure had no significant effect on the portal or hepatic artery blood flows The only significant change was observed in the portal $\mathrm{pO}_{2}$ This pressure increased from $60 \mathrm{~mm} \mathrm{Hg}$, room aur, to $600 \mathrm{~mm} \mathrm{Hg}$ at 2 atmospheres of pressure with 100 per cent $\mathrm{O}_{2}$, 


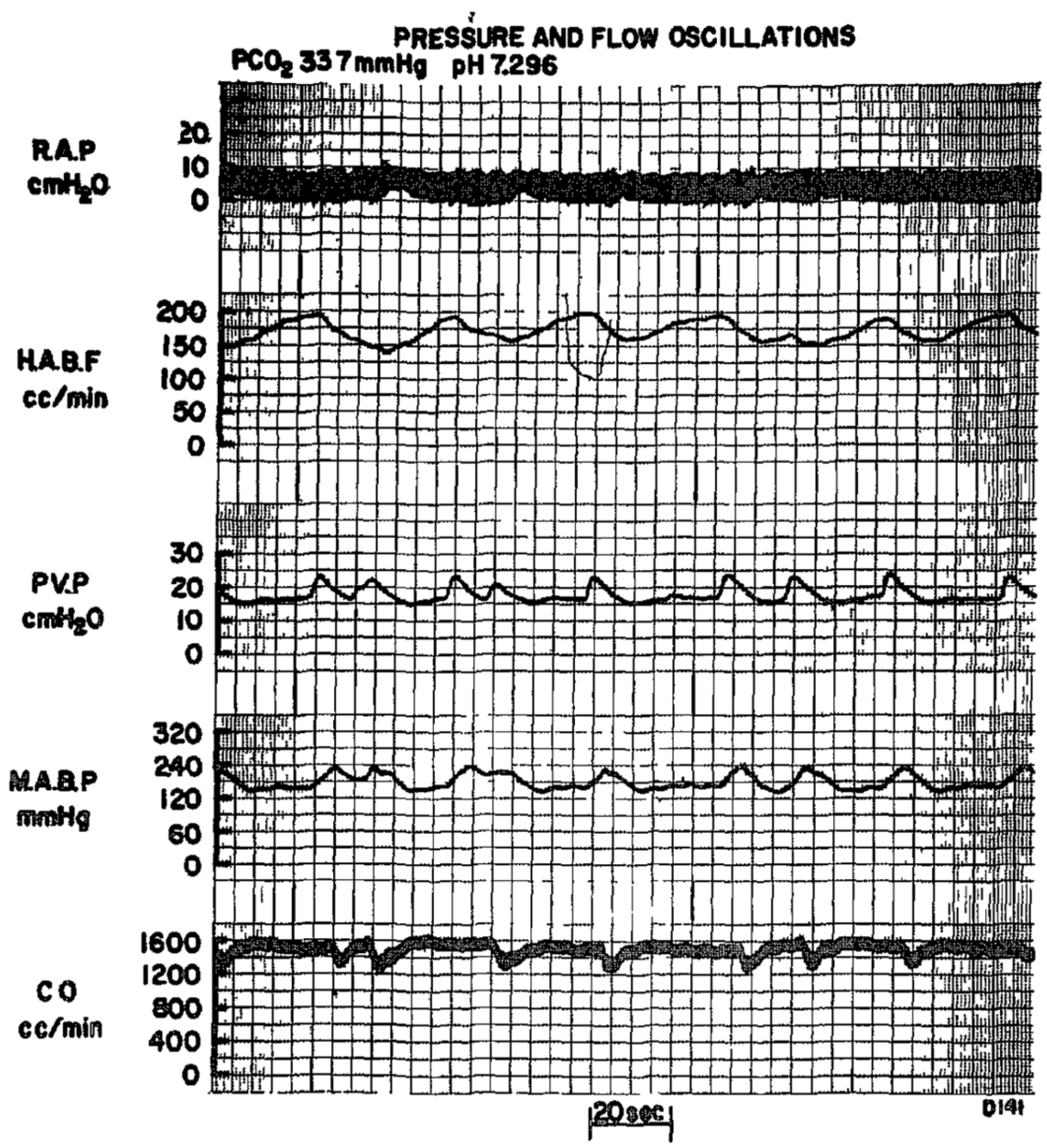

Figune 2 Blood flow oscllations in the hepatsc artery $R A P=$ right atral pressu $e$ HA B $=$ hepatic artery blood flow $P V P=p$ rtal $v$ n p essu $M A B P=$ Mean arter al blood pressure $\mathrm{CO}=$ cardiac output

although there was some indinidual variation The effect of the splenic circula tion on the portal $\mathrm{pO}_{2}$ values is currently under study in this laboratory

Carbon dioxide had a significant effect on hepatic blood flow (Table II) It decreased hepatsc artery vascular resistance and increased its flow Portal pres sure and portal $p \mathrm{O}$ were increased as result of a higher portal blood flow However the admunstration of $\mathrm{CO}_{2}$ under metabolic acidosis or maximum sympathetic stimulation had no significant effect on hepatic haemodynamics or decreased the hepatic artery and portal vein blood flow accordung to its systemic effect (These observations are presented and compared with the effect of hyper carbia under various anaesthetic conditions in work now in preparation for publication ) 
TABLE I

Changes in Portal $p \mathrm{O}_{2}$ and $p \mathrm{CO}_{2}$ as Related to Portal Blood Flow and Arterial Oxygen TENSION

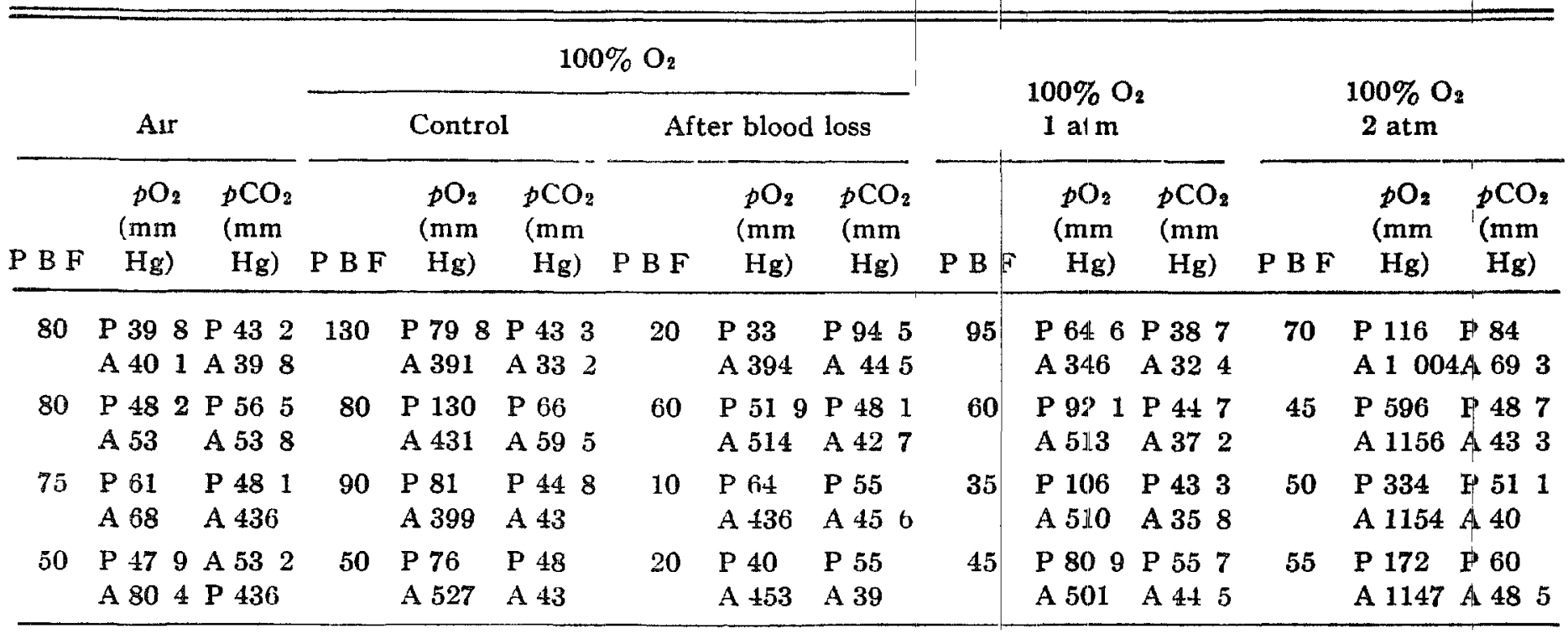

$\mathrm{PBF}=$ portal vein blood flow in flow units

$P=$ portal

$A=$ arterial

TABLE II

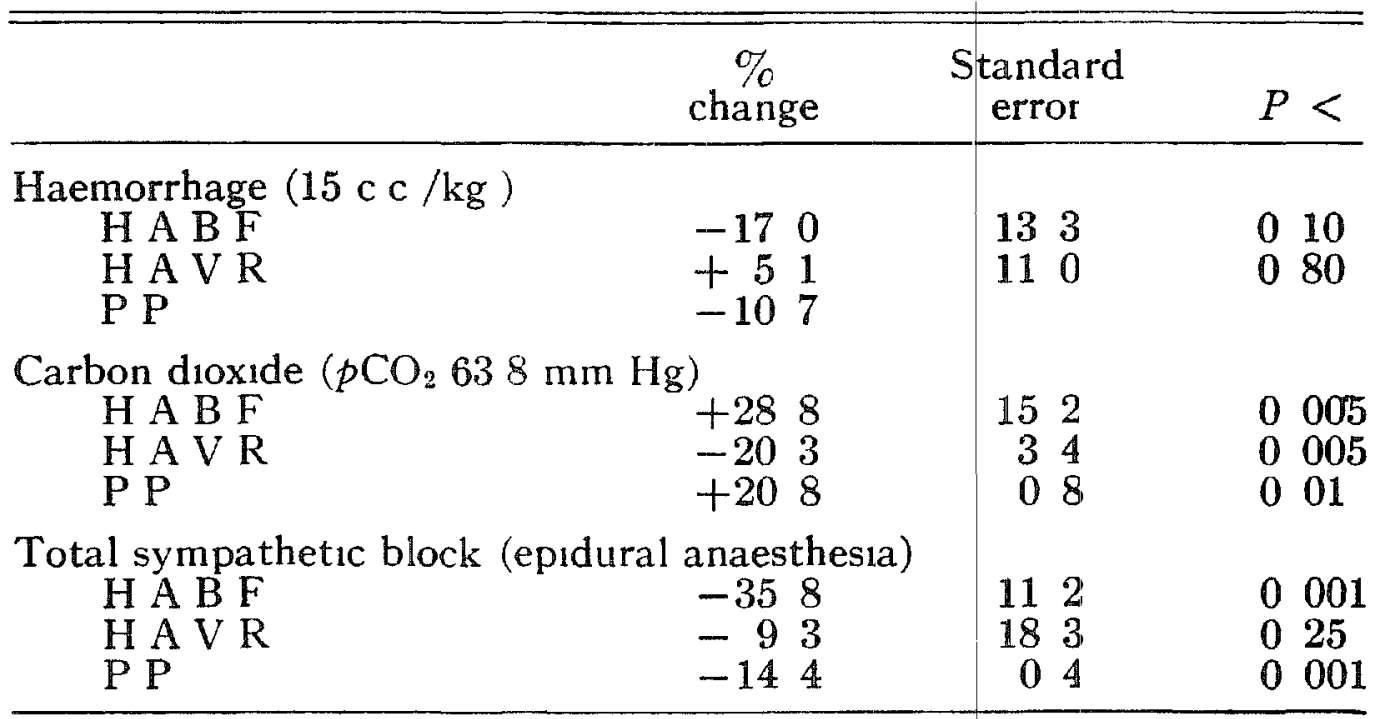

H A B F = hepatic artery blood flow

H A V R = hepatic artery vascular resistance

$P P=$ portal vein pressure

Metabolic acidosis ( $\mathrm{pH}<730$ at normal $p \mathrm{CO}_{2}$ ) following haemorrhage, hypotension, or hypoxia greatly decreased the hepatic attery blood flow in all expenments in which they occurred $\mathrm{pH}$ correction with sodium bicarbonate improved the hepatic curculation ( $\mathbb{F}_{1}$ 4)

\section{Effects of Haemorrhage}

During the early stages of haemorrhage $(10-15 \mathrm{cc} / \mathrm{kg})$, hepatic arterial blood flow did not fall, however, it fell after further bleeding $(20 \mathrm{c} \mathrm{c} / \mathrm{kg})$ and/ or haemorrhagic acidosis The portal pressure and flow were depressed from the beginning of the haemorrhage (Table I) A blood transfusion given immedrately after severe bleeding $(20 \mathrm{cc} / \mathrm{kg})$ corrected this hepatic circulatory 
imparrment Cold ( $8^{\circ} \mathrm{C}$ ) blood administration ( $20 \mathrm{cc}$. in 3 minutes) resulted in a transient reduction of blood flow in the hepatic artery lasting 1 to 5 minutes

\section{Effects of Sympathetic Block}

Total sympathetic block decreased hepatic blood flow The "hepatic waves" disappeared (Table II and $F_{1 g} 3$ ) The hepatic curculation subsequently recovered

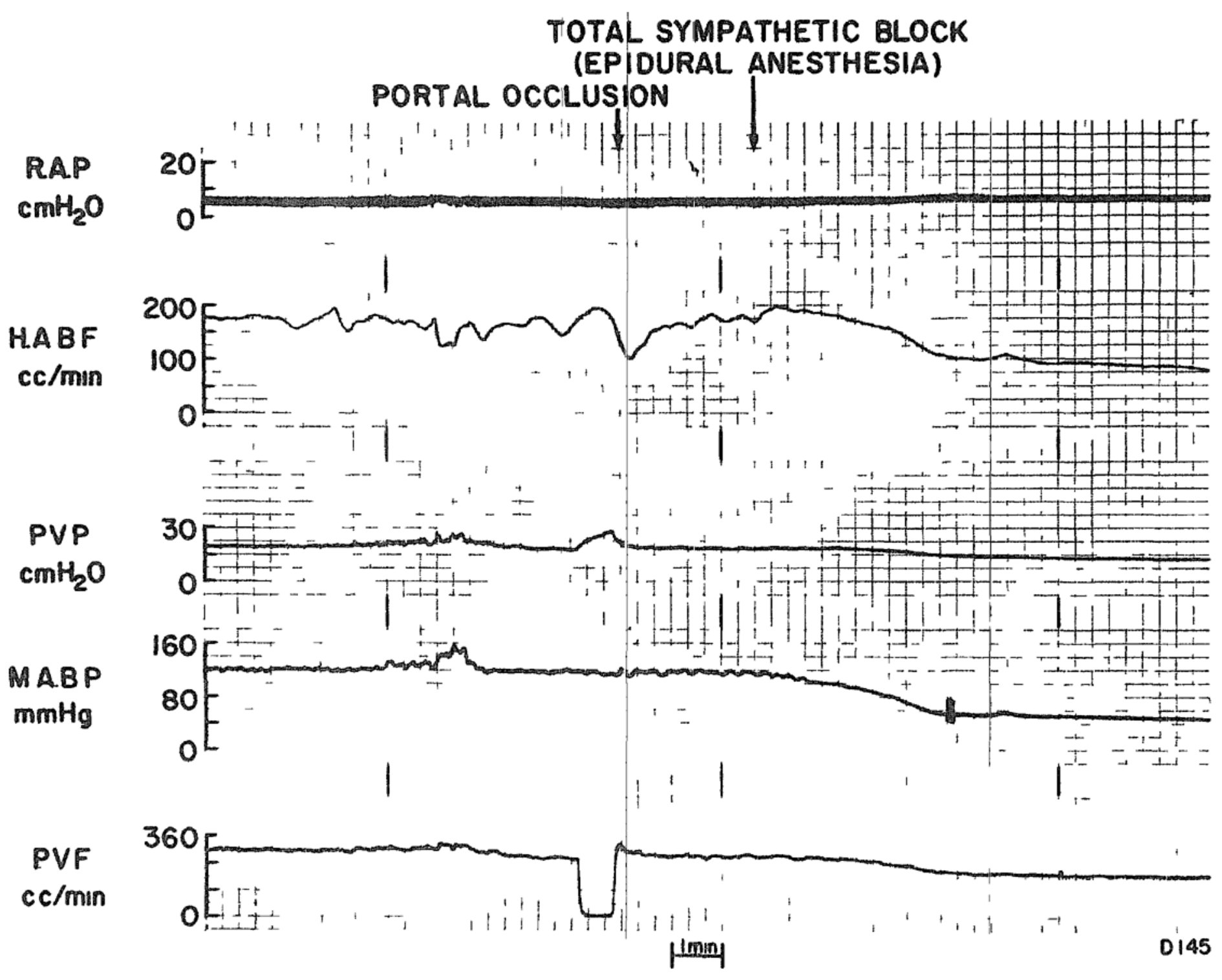

Figune 3 Total sympathetic block abollshed the hepatic artery blood-flow oscillations and depressed hepatic blood flow $\mathbb{P V F}=$ portal vein blood flow, other abbreviations as in Figure 2

\section{Effects of Local Trauma}

Traumatic compression of the hepatic hllus in 10 anmals decreased the hepatic artery blood flow, its recovery was slow Inflitration of the hepatic hilus with local anaesthesia in five dogs or total sympathetic block in three anmals had a munor protective effect against this type of trauma

\section{Effects of Adminustration of Vasopressoil Drugs}

The intravenous administration of epinephine increased hepatic artery blood flow in all experments This was noteworthy in two depressed anmals (low cardiac output and arterial hypotension, Fig 5). However, its intraportal admini-

\footnotetext{
-Changes in portal blood flow were inconsistent, it mostly increased
} 


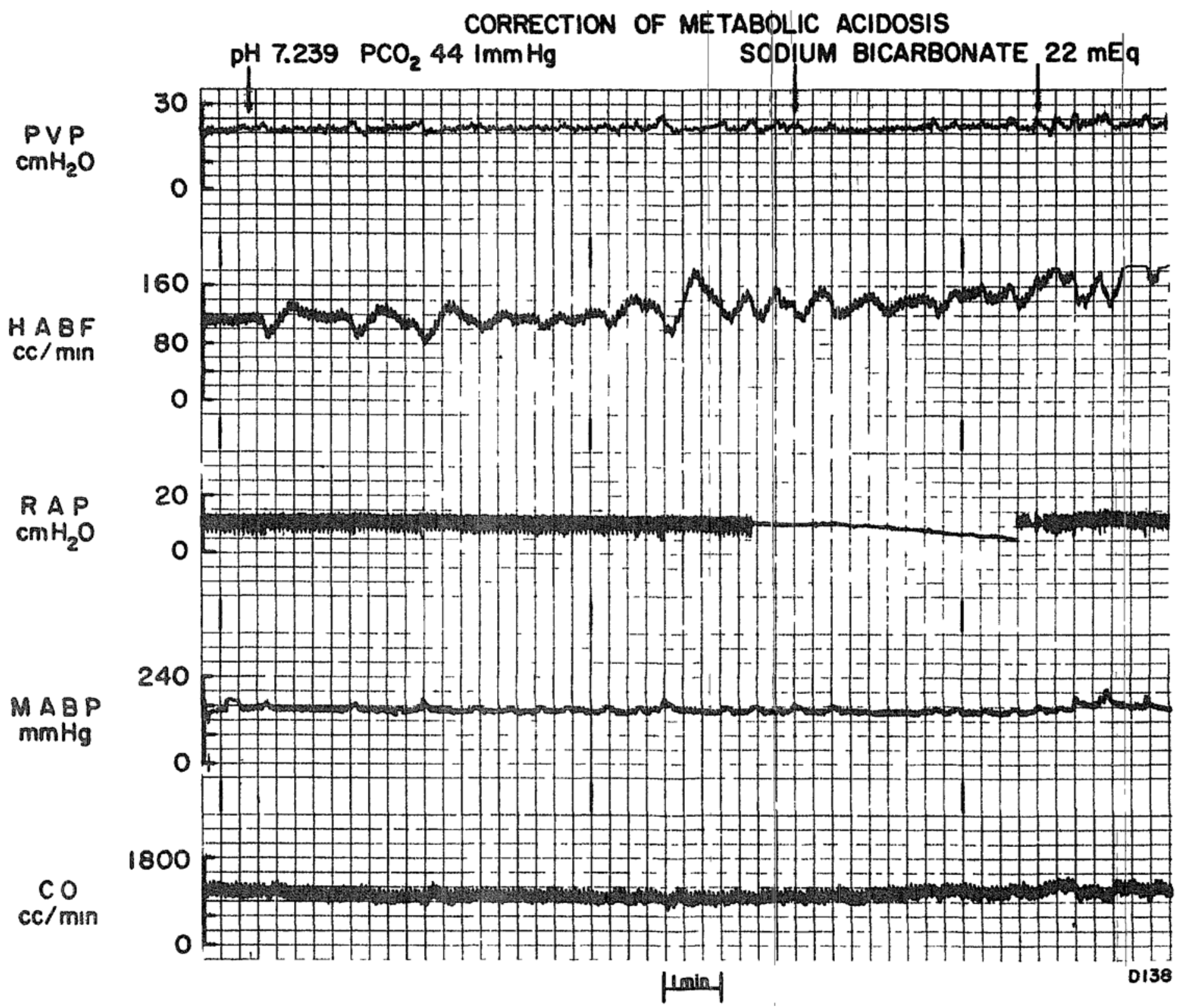

Figure 4 Metabolic acidosis depressed hepatic artery blood flow Its correction restored the flow (Abbreviations as in Figure 2)

stration produced vasoconstriction of the hepatic drtery and the portal vein (Fig 6)

Simular but less marked results were obtamed with norepmephrine when administered systematically or through the portal vein.

Table III summarizes the results obtained after intravenous and intraportal administration of various phan macological agents The changes noted were found consistently Intraportal injections of histamine or acetylcholine increased the hepatic artery blood flow with no significant effert elsewhere Methoxamine increased the systemic blood pressure but decreased the hepatic artery blood flow Mephentermine increased the hepatic arterial and portal venous blood How Metaraminol increased hepatic artery blood flow and portal vein blood flow Isoproterenol decreased the resistance in both the hepatic artery and the portal vein, while opposite results were obtamed with ephedrune

\section{Discussion}

The arterial blood supply of the liver is capable of compensatory adjustments and has some degree of independence of arterial blood pressure It is responsive 


\section{R.AP $\mathrm{CmH}_{2} \mathrm{O}$}

HABF Cc/min

\section{PVP $\mathrm{CmH}_{2} \mathrm{O}$}

\section{MABP $\mathrm{mmHg}$}

P.V.B.F.
cc/min

EPINEPHRINE INJECTION (40 $\mu \mathrm{gm})$
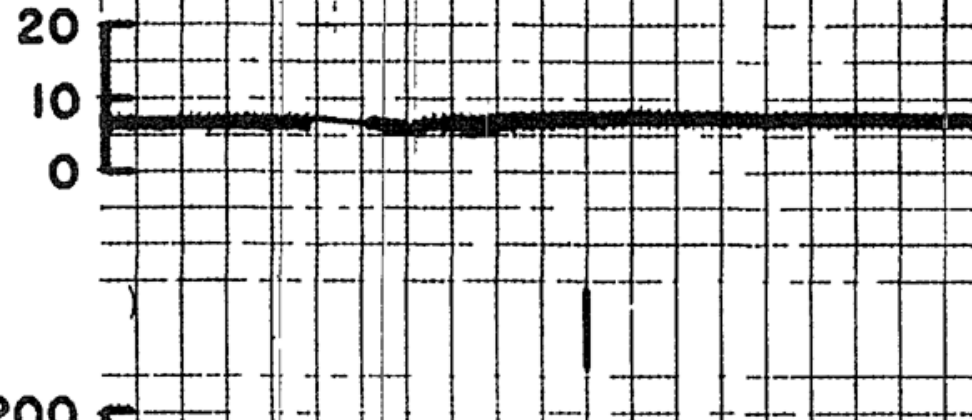

200

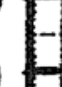

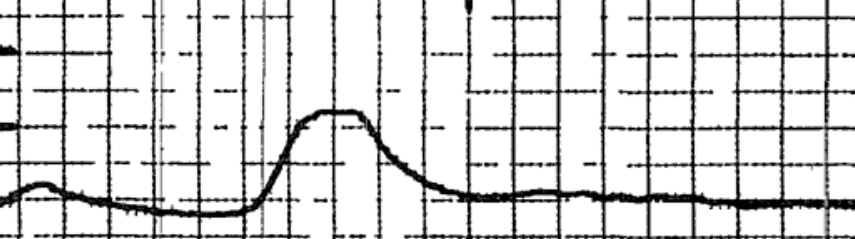

100

-

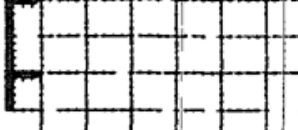

0

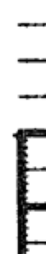

10


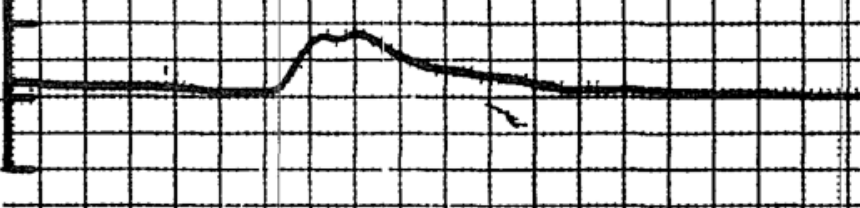

60

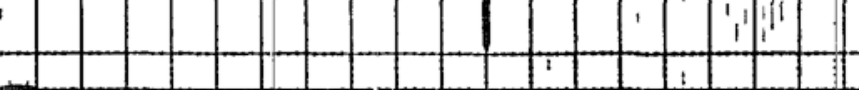

120

80

40

0

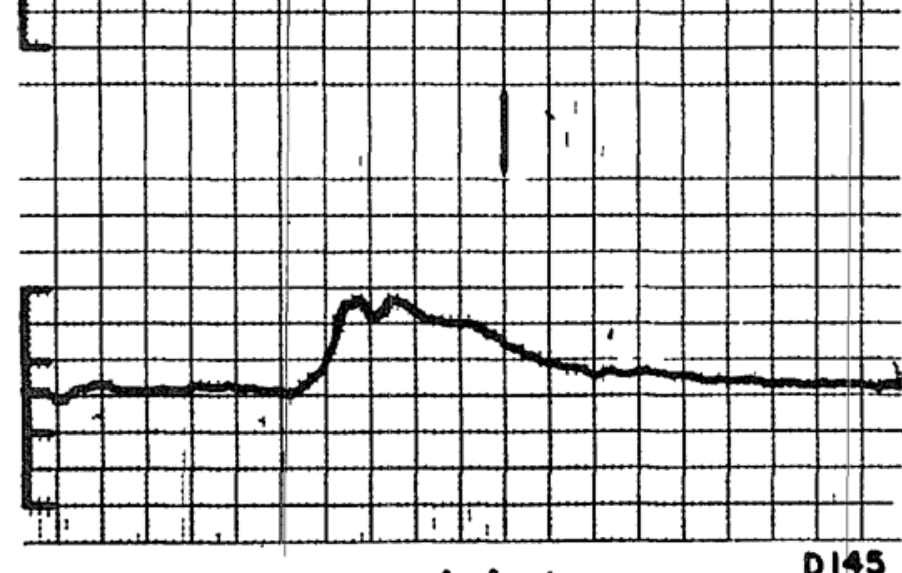

$|\min |$

Figure 5 The systemic administration of epinephrne, especially in depressed animals, imp oved the hepatic circulation P V B F $=$ portal vein blood flow, other abbreviations as in Figure 2 
INTRA PORTAL INJECTION OF EPINEPHRINE EPINEPHRINE $4 \mu \mathrm{gm}$

RAP.

$\mathrm{CmH}_{2} \mathrm{O}$

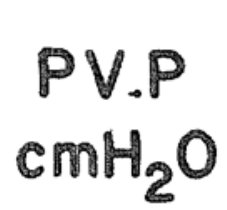

HABF

cc/mın
20

10

0

30

20

10

0

160

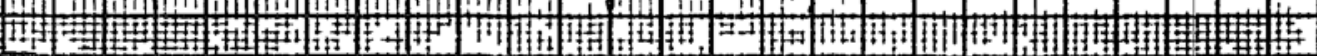

(1)

1)

(1)

$(1)$
2

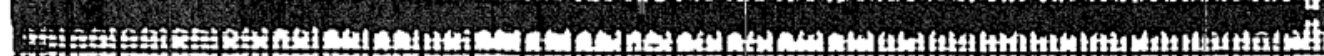

(2) 1 +

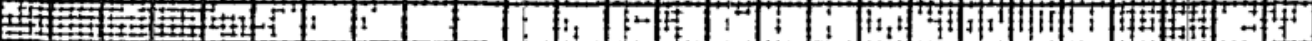
(2) : : : : | 鼓厓 (2) (5)

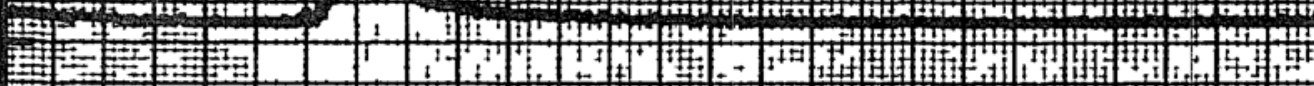

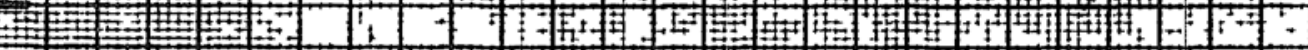

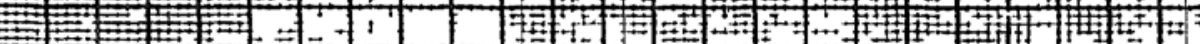

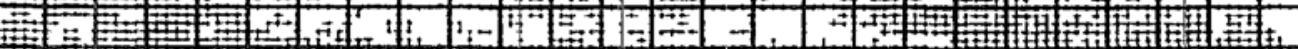

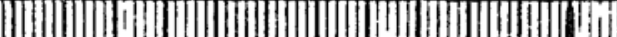
(n) (1)

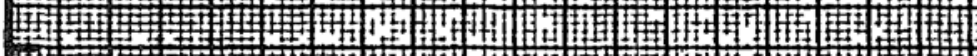

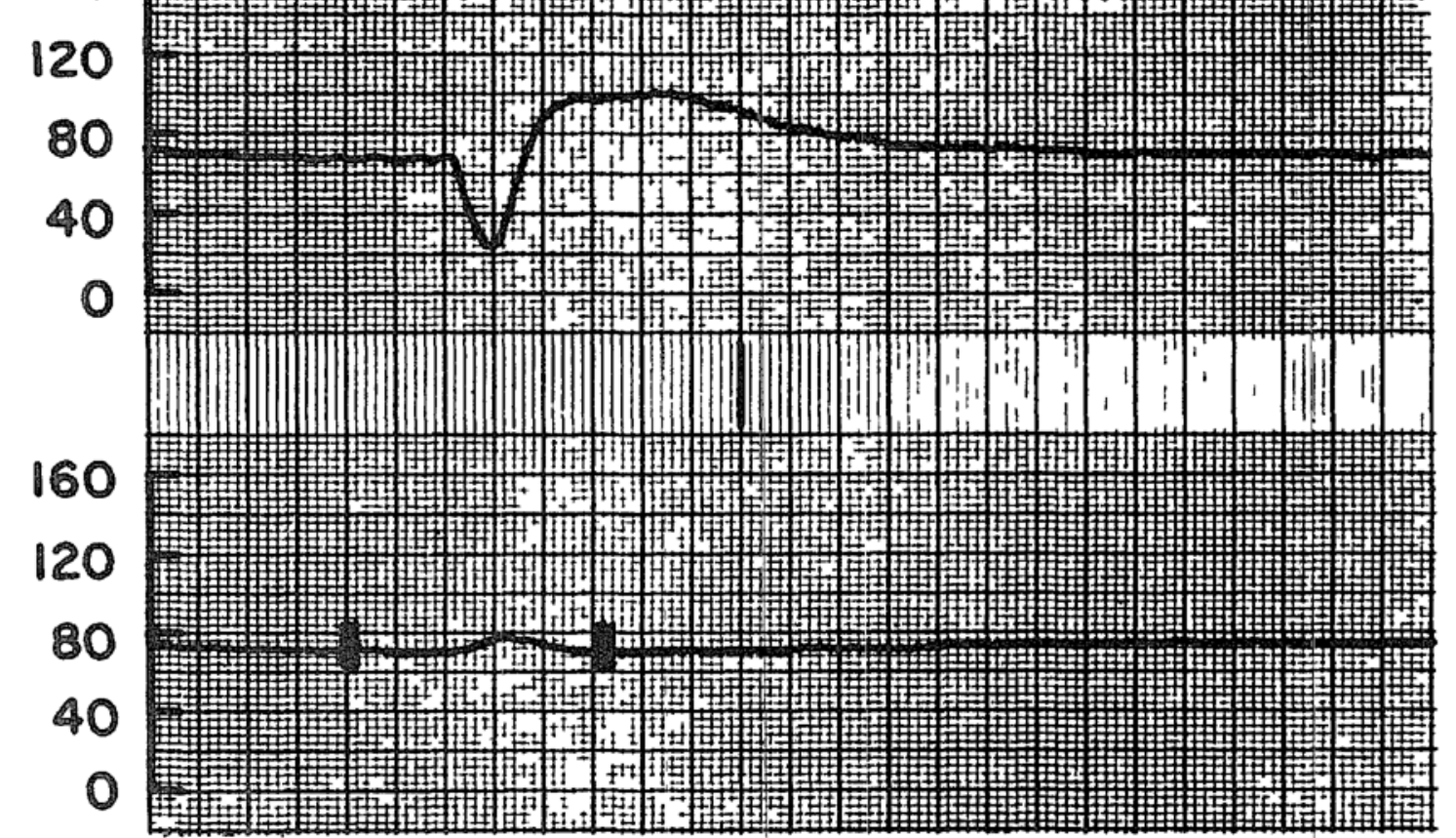

$$
\text { |iman }
$$

D 122

FIGURE 6 Intraportal epinephrne produced constriction of the portal vein and the hepatic artery, there was a postnjection vasodilatation in the latter vessel Abbreviations as in Figures 1 and 2

to changes in blood $\mathrm{pH}$ and $\mathrm{COO}_{2}$ On the other hand, portal blood flow is passively dependent upon systemic artenal blood pressure and central venous pressure The difference between these two vessels is evident during mild haemorrhage, in which case the arterial flow is sustaned and the portal flow decreased Preservation of the arterial blood flow of the liver, durnng systemic depiession (lower cardiac output and/or arterial hypotension) as might occur 
TABLE III

Directional Changes in the Hepatic Circulation as Produced by Various Pharmacologic Agents and MetaBOLIC ACIDOSIS

\begin{tabular}{|c|c|c|c|c|c|c|}
\hline & \multicolumn{2}{|c|}{ H A B F } & \multicolumn{2}{|c|}{ H A V R } & \multicolumn{2}{|c|}{ P V B F } \\
\hline & I V & I P & I V & I P & I V & I P \\
\hline $\begin{array}{l}\text { Epınephrine } \\
\text { Norepınephrine } \\
\text { Histamine } \\
\text { Acetylcholıne } \\
\text { Metabolic acidosis } \\
\text { Metoxamine (Vasoxyl) } \\
\text { Mephentermine (Wyamıne) } \\
\text { Metaraminol (Aramıne) } \\
\text { Isoproterenol (Isuprel) } \\
\text { Ephedrine }\end{array}$ & $\begin{array}{r}\downarrow \\
\downarrow\end{array}$ & $\uparrow$ & $\uparrow$ & 1 & $\stackrel{\uparrow}{\uparrow}$ & $\overline{-}$ \\
\hline
\end{tabular}

H A B F $=$ hepatic artery blood flow

H A V R = hepatic artery valscular resistance

$\mathrm{PVBF}=$ portal vein blood flow

$\begin{aligned} \uparrow & =\text { increase } \\ & =\text { decrease } \\ \text { I } V & =\text { intravenous injedtion } \\ \text { I P } & =\text { intraportal injec lion } \\ - & =\text { inconsistent results }\end{aligned}$

during or immediately after surgery, is important in the prevention of hepatic damage since during systemic arterial hypotension the oxygen supply through the portal vein is decreased while the $p \mathrm{CO}_{2}$ of this vein is increased Thus, hepatic $\mathrm{O}_{2}$ consumption becomes more dependent on the hepatic artery blood flow

Systemic administration of catecholamines (epinephrine and norepinephrine) improves the hepatic circulation This could explain the early response of the hepatic artery to haemorrhage and also to carbon dioxide mhalation, similar observations have been reported previously ${ }^{33-35}$ However, these two agents produce local vasoconstriction of the hepatic vessels when given intraportally

An intrinsic control of the hepatic circulation is suggested by the vasoconstriction produced by trauma, this reaction has been reported before ${ }^{\mathbf{s} 6}$ and can also be obtained by local sympathetic nervous stımulation ${ }^{27}$ This may be an explanation for the "outflow block," or great increase in hepatic vascular resistance, reported during the first 45 minutes of liver perfusion experiments

The effect of carbon dioxide is basically similar to that obtained in a previous study in $\operatorname{man}^{37}$ and dog, in which $\mathrm{CO}_{2}$ stimulated or depressed hepatic blood flow according to the depth of anaesthesia and kind of anaesthetic agent and the systemic arterial pressure changes

The hepatic artery blood-flow oscillations ("hepatic waves") could be produced by a vaso-active agent, released in the mesentenc or splenic circulation The function and importance of this oscillation is unknown at present Previous reports describe oscillations but of different nature since flow determmations were not made in a continuous manner ${ }^{38}$

These observations confirm the presence of several mechanisms by which hepatic oxygen supply can be modified during a surgical operation, independent of the anaesthetic agent or the depth of anaesthesia 


\section{SUMMARY}

A technique for hepatic blood-flow determinations is described The hepatic artery blood flow was found to have some degree of undependence of the arterial blood pressure, while the portal flow followed systemic curculatory changes Trauma to the liver, metabolic acidosis, or total sympathetic block depressed hepatic artery blood flow Carbon dioxide, epinephine, or norepinephrme increased the hepatic artery blood flow, however, this effect was related to their systemic curculatory changes Several factors decieased portal oxygen saturation

\section{RÉSUMÉ}

L'auteur décrit une technıque de détermination des débits sanguins hépatıques Tandis que le débit de l'artère hépatique semblait être indépendant de la pressıon artérielle, celuı de la veine porte suıvant les varnations curculatoures systémiques

Les baumatismes au fore, l'acidose métabolique, le blocage complet du système sympathique diminuaient le débit de l'artère hépatique Le bıoxyde de carbone en l'absence d'acidose métabolıque, l'épınéphrine, la norépınéphrine augmentaient le débit de l'artère hépatique, cependant Il faut rattacher ce dernier effet à leurs changements curculatorres systémıques Parmı les nombreux facteurs diminuant la saturation en oxygène du sang porte, la cluminution du débit sangum dans la veine porte était le plus important

\section{REFERENCES}

1 Grenn, N D, Ngai, S H, Sulak, M H, Crow, J G , \& Slocum, H C Effects of Anesthetic Agents on Hepakc Structure and Function in Dogs Anesthesiology 20776 (1959)

2 Jones, W M, Margolis, G, \& STEPHEN, C R Hepatotoxicity of Inhalation Anesthetic Drugs Anesthesiology 19715 (1958)

3 Moris, L E \& Feldman, S A Influence of Hypercarbia and Hypotension upon Liver Damage Following Halothane Anesthesia Anaesthesia 1832 (1963)

4 Brojy, G L \& Sweet, R B Halothane Anesthesia as a Possible Cause of Massive Hepatic Necrosis Anesthesiology 2429 (1963)

5 Litrte, D M, Barbour, C M, \& Grven, J G The Effects of Fluothane, Cyclopropane, and Ether Anesthesia on Liver Function Surg, Gynec. \& Obst 107712 (1958)

6 Popper, H \& Schaffrner, F Drug-Induced Hepatic Injury Ann Int Med 511203 (1959)

7 Popper, H \& Frankin, M Viral Versus Toxic Hepatic Necrosis Arch Pathol 46338 (1948)

8 Gardner, G H, Group, $R$ C, Gustafson, $\mathbb{R}$ K, Matte, E D, Thomas, M J, Wells, II S, \& Lamson, P D Studies on the Pathological Histology of Experimental Carbon Tetrachlonde Poisoning Bull I Hopkns Hosp 36107 (1925)

9 Shoemaker, W C, Szanto, $\mathbb{P}$ B , Fitch, L B \& Brill, N R Hepatic Physiology and Morphologic Alterations in Hemorrhagic Shock Surg, Gynec \& Obst 118828 (1964)

10 Mrrrs, J D \& Hicram, J E An Estumation of the Hepatic Blood Flow and Splanchmic Oxygen Consumption in Heart Falure J Clin Invest 27620 (1958)

11 REFSUM, H E Artenal Hypoxemia, Serum Activities of SGOT and SGPT and LDH and Centrolobular Liver Cell Necrosis in Pulmonary Insufficiency Clin Sci 25269 (1963)

12 Benitez, $R$ M Degenerative Changes in Liver Associated with Aspiration of Vernix and Myeline Membrane Formation in Lungs in Intrauterine Anoxa A M A Arch Pathol. $54378(1952)$ 
13 AltmanN, H W Uber Leververanderurgen bein allgemeinem Sauerstoffmangel, nach Unterdruckexperimenten an Katzen Frankfurter Z Pathol 60366 (1949)

14 Myeirs, J D , Brannon, E S, \& Holland, B C A Correlative Study of the Cardiac Output and the Hepatic Circulation 11 Hyperthryroidısm J Clin Invest 291069 (1950)

15 Moore, $\mathrm{K}$ E \& Brody, $\mathrm{T}$ M Function ll Changes in Liver Mitochondria Following in situ Anoxia Am J Physiol 198677 (1960)

16 Calvert, D N \& Brody, $T$ M Role of the Sympathetic Nervous System in CCl, Hepatotoxicity Am J Physiol 198669 (1960)

17 Влору, T M Some Aspects of Experimental Carbon Tetrachlonde-Induced Hepatotoxicity Ann N Y Acad Sc1 1041065 (1963)

18 Larson, $\mathrm{R}$ E \& PLAA, $\mathrm{G}$ Effect of Spinal Cord Transection on $\mathrm{CCl}_{4}$ Hepatotoxicity Fed Proc 22189 (1963)

19 Goldschmmt, S, Ravdin, S I, \& Lucke, B Anesthesia and Liver Damage I The Protective Action of Oxygen against the Necrotizing Effect of Certain Anesthetics on the Liver J Pharmacol \& Exper Therap 5o 1 (1937)

20 Sngs, J L, Morrus, L E, ORTh, O S, \& WATERS, $\mathbb{R}$ M The Influence of Oxygen and Carbon Dioxide Levels during Anesthesia upon Postsurgical Hepatic Damage J Lab Clin Med 38388 (1951)

21 Brauer, R W Liver Circulation and Funtion Physiol Rev 43115 (1963)

22 Brauer, $R$ W, Leong, $G$ F, \& Hollow $1 Y, \mathbb{R} J$ Liver Injury in Isolated Perfused $\mathbf{R} t$ Liver Preparation Exposed to Chlow oform Am J Physiol 200548 (1961)

23 Cameron, $G \mathbb{R}$, Karunaratine, W, A $E$, \& Thomas, J G Massive Necrosis (Toxic Infraction) of the Liver Following Intra portal Administration of Poisons J Pathol Bact 44297 (1957)

24 Grynn, L E \& Himsworth, H P The Intralobular Circulation in Acute Liver Injury by Carbon Tetrachlonde Clin Sci 6235 (1948)

25 Bradley, $S$ E, Ingelfinger, $F$ J, BradLeY, G P, \& Curry, J J The Estumation of Hepatic Blood Flow in Man J Clin Invest 24890 (1944)

26 Levy, M L, Palazzi, H M, Nardi, G L, \& Bunker, J P Hepatic Blood Flow Variations during Surgical Anesthesia in Man Measured by Radioactive Collord Surg, Gynec \& Obst 112289 (1961)

27 Shozmaker, C P A Study of Hepatic Hemodynamics in the Dog Circ Res 15216 (1964)

28 Eisman, B , Knipe, P, KoH, Y , Normeli, L, \& Spencer, F C Factols Affectung Hepatic Vascular Resistance in the Perfused Liver Ann Surg 157532 (1963)

29 Greenfield, J C JR, Patrel, D J, Mallos, A J, \& Fry, D L Evaluation of Kolin Type Electromagnehc Flowmeter and the Pressure Gradient Technique J Appl Physiol 17372 (1962)

30 Tetirick, J E \& Mencoli, L Calibration and Use of Square-wave Electromagnetic Flowmeter Surgery 54621 (1963)

31 Spencer, M $\mathrm{P}$ \& Denison, A B Jn Square Wave Electromagnetic Flowmeter for Surgical and Experimental Application Meth Med Res 8321 (1960)

32 CoHn, $\mathbf{R}$ \& Kountz, $S$ Factors Infuenting Control of Arterial Circulation in the Liver of the Dog Am J Physiol 2051260 (1963)

33 Bearn, A G, Billing, B, \& Sherlock, s The Effect of Adrenaline and Nor-adrenaline on Hepatic Blood Flow and Splanchnic Carbohydrate Metabolism in Man I Physiol 115430 (1951)

34 Daniel, P M \& Prichard, M M L Effects of Stumulation of Hepatic Nerves and of Adrenaline upon the Circulation of the Portal Venous Blood within the Liver J Physiol 114538 (1951)

35 Burton-Opitz, $\mathbb{R}$ The Vasculanty of the Liver VIII The Influence of Adrenaline upon the Arterial Inflow Quart J Exp Physiol 5309 (1912)

36 Bausr, W, Dale, H H , Poulsson, L T., \& Richards, D W The Control of Circulation through the Liver J Physiol 74343 (1932)

37 Epstern, $R$ M, Whellef, $H$ O, Frumun, M J, Habif, $D$ V, Papper, E M, \& BradLEY, S E The Effect of Hypercapnıa on Estamated Hepatic Blood Flow, Circulating Splanchnic Blood Volume, and Hepatic Sulfobromophthalem Clearance during General Anesthesia in Man J Clin Invest $40 \quad 592$ (1961) 